\title{
Exchange Rate Pass-Through in ASEAN: Implications for the Prospects of Monetary Integration in the Region
}

\author{
Carlos Cortinhas*
}

January 12, 2007

\begin{abstract}
This paper investigates, for the first time, the degree of exchange rate pass-through to domestic prices in all five founding members of ASEAN. For this purpose, a three variable recursive VAR model was applied which uses the Choleski decomposition method along the distribution chain of pricing, using data for the period 1968 to 2001. The results show that a strong case for entering a currency union can only be made for the cases of Singapore and Malaysia as in these countries there appears to be a case of exchange rate disconnect. A case for a common currency can also be made for Indonesia but for entirely different reasons. For this country, an independent monetary policy is a clear source of shocks to the economy and therefore a currency union would tend to eliminate then. A weaker case for a common currency can be made for the Philippines as evidence of some exchange rate pass-through to inflation was found but not to import prices. Finally, Thailand exhibits a clear case of exchange rate passthrough to import prices (but not to inflation) and thus evidence that a flexible exchange rate might be preferable as it provides the means to improve the country's price competitiveness.
\end{abstract}

Keywords; Exchange Rate Pass-Through; Monetary Integration; Asean.

JEL Classifications: F31; F33; E42

\footnotetext{
* The Economic Policies Research Unit (NIPE), The University of Minho, Portugal; ccortinhas@eeg.uminho.pt. I would like to thank John Maloney and Nigar Hashimzade of The University of Exeter for useful comments and suggestions. The usual disclaimer applies.
} 


\section{Introduction}

The majority of studies to date on the suitability for a currency union amongst the five largest ASEAN economies (ASEAN5) focused on the asymmetry of shocks affecting those countries and points towards the existence of a core group comprising Indonesia, Malaysia and Singapore that is in better position to move faster towards the constitution of a monetary union than a periphery composed of the Philippines and Thailand $^{1}$. Furthermore, most studies found that the average size of demand, monetary and supply shocks is much larger in ASEAN than in both the Euro-zone countries and the USA. Conversely, the speed of adjustment to shocks is much faster in ASEAN than both the EU and the USA. In this way, the existing empirical literature seems to agree that, if not all of ASEAN5, at least the core group appears to be a viable monetary union even if it does not fare as well when comparing with the EU countries before the introduction of the euro (or the USA).

The faster speed of adjustment to shocks in ASEAN raises the question of whether the necessary adjustment to restore equilibrium is coming from changes in nominal exchange rate or from other sources. If it is the nominal exchange rate that is providing most of the adjustment, the region's prospects for further monetary integration are limited. Conversely, if the adjustment is coming from other sources, most notably labour and wage changes, a currency union can be seen as a feasible endeavour. The latter, however, cannot easily be tested empirically as no systematic data is available for this group of countries ${ }^{2}$.

The purpose of this paper is to provide a study on the degree of relative price adjustment in ASEAN5 in order to draw inferences to their suitability for further monetary cooperation.

The existing optimum currency area (OCA) theory suggests that in the presence of large asymmetric (country-specific) shocks without the appropriate adjustment mechanisms, countries should not attempt to join or create a common currency as the costs of having a fixed exchange rate would greatly outweigh the benefits of such

\footnotetext{
${ }^{1}$ Examples include Bayoumi and Eichengreen (1994), Bayoumi and Eichengreen (1996), Bayoumi, Eichengreen and Mauro (2000), Yuen (2000), Bayoumi and Mauro (2001) and Zhang, Sato and MacAleer (2004).

${ }^{2}$ These, however, are expected to play an important role in the region. Bayoumi and Mauro (2001), for example, suggest that the reason for a faster speed of adjustment to shocks in ASEAN is due to the fact that the labour market and wage rates are more flexible in ASEAN which makes it easier for these countries to adjust internally to shocks.
} 
policy $^{3}$. Under the traditional assumptions that factors of production are not as mobile externally as they are internally and are of limited price and wage flexibility, the necessary adjustment of the real exchange to an asymmetric shock can be quickly achieved by adjustment of the nominal exchange rate. Under a monetary union (or other fixed exchange rate regime) any adjustment in the real exchange rate can only come from adjustment in the relative inflation levels. If wages and prices are slow to adjust, this could lead to prolonged periods of real exchange rate misalignments which would bring large and prolonged costs to the economy.

Therefore, when accessing whether any two countries fulfil the pre-conditions to form a currency union, it is not only important to study the degree of real relative price level adjustment to an asymmetric shock but especially to determine whether the flexibility accrues from nominal exchange rate changes or changes in the relative consumer price levels ${ }^{4}$. As pointed out by Artis and Ehrmann (2006), exchange rates can work both as a shock-absorber and a source of shocks and therefore, the determination of the effective role played by the exchange rate is a critical issue for countries where a monetary union (or other quasi-union arrangements) is a open policy option $^{5}$.

For the nominal exchange rate to work as an adjustment mechanism, changes in the nominal exchange rate must increase the consumer price of imported goods relative to domestic goods, thereby leading to a strong expenditure-switching effect, i.e, encouraging consumers to buy domestic rather than foreign produced goods. For macroeconomic policy purposes it is essential to distinguish between the impact of changes in the nominal exchange rate on import prices and on consumer prices.

A popular way to investigate these matters is provided by the literature of exchange rate pass-through ${ }^{6}$. The theory of the determination of exchange rate passthrough goes back to the debate over the (failure of the) law of one price and has since moved to industrial organization models where the role that different market structures

\footnotetext{
${ }^{3}$ Frankel and Rose $(1997,1998)$ offer a conflicting view with their now famous endogeneity of OCA criteria argument, suggesting that a country is more likely to satisfy the criteria for entry into a monetary union ex post than ex ante due to lowered asymmetrical shocks.

${ }^{4}$ In this way, the evidence found in several studies, like Rogers and Jenkins (1995), Engel, Hendrickson and Rogers (1997) and Rose and Engel (2002), of the existence of no difference between intra-national and international speeds of convergence of aggregate real exchange rates cannot be seen as proof that (for the countries under analysis) a rigid exchange rate system would be preferable. In fact, evidence of the opposite result has also been found (see for example Bayoumi and Thomas (1995)).

${ }_{5}^{5}$ Buitter (2000) pointed out that flexible exchange rates are unlikely to provide adjustment to imbalances caused by long-term real rigidities in the economy and concludes that in a setting of high degree of international financial integration (but also in case of closed economies), fully flexible exchange rates are primarily a source of shocks and instability.

${ }^{6}$ For the key terms "law of one price", "purchasing power parity", "exchange rate pass-through" and "pricing to market" Goldberg and Knetter (1997) reported that EconLit gives approximately 700 entries published from the 1970s. Restricting the search to "exchange rate pass-through", Econlit returns a total of 255 entries at the end of 2006.
} 
and the price discrimination of exporting firms plays in determining import prices. In more recent years, the debate has enlarged to include discussions over appropriate monetary policies and the optimal choice of exchange rate regimes ${ }^{7}$.

The main motivation for most of the ongoing debate is the substantial empirical evidence on the limited pass-through of nominal exchange rate movements and the fact that there appears to be a declining trend in the pass-through rates over time in a large number of countries ${ }^{8}$. Most recent theoretical works in this area try to explain these phenomena and essentially do so by discussing either (i) the prevalence of local currency pricing (LCP) over producer-currency pricing (PCP) or (ii) whether exchange rate pass-through rates are endogeneous to a country's inflation performance.

The former, of which Devereux and Engel (2003) is a recent prominent example, argue that if PCP dominates, the exchange rate pass-through to domestic prices is immediate and exchange rate flexibility plays a central part of an optimal monetary policy. If, however, LCP dominates, the exporters keep their prices fixed in the foreign currency and accept the resulting domestic price at the prevailing exchange rate. The exporting firm's willingness to reduce its profit margin in case of a nominal exchange rate appreciation prevents any pass-through from nominal exchange rates into import and ultimately consumer prices, implying that the optimal monetary policy would be a fixed exchange rate.

The latter, originally put forward by Taylor (2000), argues that a low inflationary environment leads to a low exchange rate pass-through to domestic prices. Using a model of firm behaviour based on staggered price setting and monopolistic competition, they show that the degree of exchange rate pass-through is regime specific and that in low inflation scenarios the effectiveness of monetary policy could be severely impaired ${ }^{9}$.

The general conclusion that most of the existing literature seems to reach is that flexible exchange rates have, at best, very limited power in functioning as an adjustment mechanism to asymmetric shocks and therefore there appears to be a strong case for fixed exchange rate regimes ${ }^{10}$.

\footnotetext{
${ }^{7}$ For extended surveys on the theory of exchange rate pass-through, see for example Menon (1995) or Goldberg and Knetter (1997). ${ }^{8}$ Gagnon and Ihrig (2004) for example, present a brief survey of empirical papers that identified a reduction in exchange rate passthorugh in various countries. For a survey of empirical works that found evidence of partial pass-through see for example Menon (1995).

${ }^{9}$ Recently, Choudri and Hakura (2006), using data from 71 countries, found strong evidence supporting Taylor's hypothesis.

${ }^{10}$ It is worth noting that there also are those who defend the opposite view. Duarte (2004), Duarte and Obstfeld (2004) and Obstfled (2006) show that the inclusion of non-traded goods in the model is enough to restore the need for exchange rate flexibility, even when shocks are real and prices are set in local currency and there is complete absence of expenditure-switching effects.
} 
As with theory studies, there are a great number of empirical studies on exchange rate pass-through to domestic prices. They vary considerably in terms of types of data, econometric methods and countries under analysis.

The data included in the empirical studies has reflected the problems under study. Early studies tended to concentrate on the study of the degree of exchange rate pass-through to import prices and have since extended to include a larger number of domestic price variables, including export prices, producer price index (PPI) and consumer price index (CPI). Similarly, depending on the scope of the study, the level of aggregation of the data used varies from micro data to industry level data and more recently aggregated level data.

Concerning the estimation techniques, a large number of alternatives can be identified, which can be roughly collated into two main categories ${ }^{11}$ : Single equation models, estimated either by OLS techniques e.g., Campa and Goldberg (2005), twostage least squares, e.g., Mihailov (2005), panel data estimation, e.g., Barhoumi (2006); the other widely used type is based on vector autoregressions (VAR), mostly by interpreting impulse-response functions (IRF). These include recursive VAR models, e.g., McCarthy (2000), Structural (or restricted) VAR models, e.g., Choudhri, Faruquee and Hakura (2005), VARs in levels with sign restrictions, e.g., An (2006), Generalized VAR impulse response models, e.g., Mihailov (2005) and Cointegration Analysis and Vector Error Correction Models, e.g., Toh and Ho (2001).

As all methods necessarily have shortcomings, there seems to be no consensus on the best econometric technique to use. The major problem of single equation based methods is the underlying assumption of the exogeneity of the regressors. This does not allow for the possibility of dual causality between variables which is of essential importance when the analysis is macroeconomic in nature. Similarly, the VAR based methods also have drawbacks which are largely related to the underlying assumptions on the IRFs. The recursive VAR models typically study exchange rate pass-through to prices at different stages of the distribution chain of pricing, most commonly import prices, PPI and CPI, using a Cholesky decomposition to identify the structural shocks. The well-known drawback of this method is that of the IRFs being sensitive to the ordering of the variables. The major problem of IRFs with imposed structural restrictions (which also applies to IRFs with sign restrictions), "has been argued to be

\footnotetext{
${ }^{11}$ For a recent survey of empirical papers on exchange rate pass-through, see for example An (2006).
} 
some degree of arbitrariness of such assumptions" $" 12$. The main virtue of the generalised impulse response method is that of not requiring the orthogonalisation of shocks and thus being invariable to the ordering of the variables but at the cost of needing an assumption for the distribution of shocks (Michailov (2006, p.15)).

All these VAR based techniques also share the problem of estimating the VAR system with stationary variables (namely by first differencing the variables) which creates estimates that are "systematically biased downwards"13. This could in theory, be avoided by the use of cointegration analysis and (vector) error correction models ${ }^{14}$. In practice, however, "an econometrician using standard tests for cointegration rank and for testing restrictions on the cointegration space would in general not be able to infer the correct rank or identify the true cointegration relations" $" 15$.

Most empirical studies on exchange rate pass-through have been conducted in terms of developed countries, most notably the United States. In recent years, however, greater attention has been given to studies that include developing economies. Despite their reduced number, studies on Asia in general and South East Asia in particular have followed this trend.

The first paper to study the exchange rate pass-through to import prices for a group of Asian countries was Webber (1999), who used cointegration techniques and error correction modelling to provide estimates of the long run and short run passthrough for nine Asia-Pacific countries, including four ASEAN members: Thailand, the Philippines, Malaysia and Singapore. Using quarterly data for the period 1978:1 to 1994:2 (1978:1 to 1987:3 for Thailand and Malaysia), he found evidence of partial, long-run pass-through into import prices in the case of the Philippines (90\%) and Singapore (77\%), but not in the case of Thailand and Malaysia.

Recently, Ito, Sasaki and Sato (2005) and Ito and Sato (2006) studied 5 East Asian countries, including four ASEAN countries, Indonesia, Thailand, Malaysia and Singapore, employing a recursive VAR model that uses monthly data for the period January 1995 to August 2005. Using a 5 variable VAR (later extended to a 7 variable VAR) to study the degree of exchange rate pass-through along the distribution chain of

\footnotetext{
${ }^{12}$ Michailov (2006), p. 6.

${ }^{13}$ Bache (2006), p. 22. He generates data from a dynamic stochastic general equilibrium model and uses Monte Carlo techniques to compare the results with the performance of different VARs. He found that a low order vector cointegration model is a good approximation to the data generating process but casts doubts on whether in practice an econometrician would be able to infer the cointegration properties implied by the DSGE model.

${ }^{14}$ VAR models with sign restrictions also use information on the variables in levels. However, the assumptions on the sign restrictions can also be seen as arbitrary.

${ }^{15}$ Bache (2006), p. 22.
} 
pricing, they showed the pass-through of exchange rate shocks to be largest on import prices, then on the PPI, with the smallest on CPI. They found that Indonesia exhibited a very large and significant response of both the CPI and the import prices to an exchange rate shock. Thailand also yielded a positive and significant response of CPI and import prices to exchange rate shocks but of much smaller magnitude than that in Indonesia. Finally, for both Malaysia and Singapore no significant response was found (only Malaysia pass-through to CPI was investigated as no data on import prices was available).

A number of studies have also focused on the exchange rate pass-through to export prices. Toh and Ho (2001) used cointegration techniques and error correction modelling to provide estimates of the long run and short run pass-through of exchange rates to export prices in four Asian countries, namely, Malaysia, Thailand, Taiwan and Singapore, using quarterly data for the period between 1975:1 and 1996:2 both at the aggregate and disaggregate levels. They showed the degree of pass-through to export prices to be $0.127,0.633,0.807$ and 0.997 , for Taiwan, Malaysia, Singapore and Thailand, respectively. Conversely, Parsons and Sato (2005) found little evidence of pass-through to export prices in their study of four ASEAN countries: Indonesia, Malaysia, The Philippines and Thailand. Applying a single equation model they estimate the exchange rate pass-through coefficients for the exports at the 6-digit industry level and found little evidence of pass-though in these countries attributing this to the fact that the ASEAN countries are price takers in a relatively integrated market rather than evidence of pricing-to-market ${ }^{16}$.

At this point several conclusions can be made. The number of empirical studies on the exchange pass-through to domestic prices in ASEAN is still meagre and does not seem to agree on the results. Also, mostly due to the unavailability of data, no study has included the five largest, founding members of ASEAN. Finally, there seems to be no agreement on the best econometric method to apply in order to investigate these matters.

The main contribution of this paper is, for the first time, to provide a study on the degree of exchange rate pass-through into domestic prices, using the distribution chain of pricing, which simultaneously includes all five founding members of ASEAN (ASEAN5) so to draw inferences on their suitability for further monetary cooperation.

\footnotetext{
${ }^{16}$ However, as stated by the authors, their results are dependent on certain modelling assumptions which are not tested (they get opposite results depending on whether the underlying assumption is imperfect or perfect competition).
} 
The empirical method and the data will be formally explained in the following section. Section 3 will present the results and section 4 a sensitivity analysis. Finally, the last section concludes the paper.

\section{Data and Empirical Methodology}

The five founding members of ASEAN, Indonesia, Malaysia, the Philippines, Singapore and Thailand, constitute the sample countries of this study. The primary objective of this paper is to estimate the impacts of exchange rate changes on domestic price variables so to estimate the expenditure-switching effect of exchange rate changes. As mentioned above, it is essential to extract the effects of exchange rate changes not only on inflation but also along the different stages of the pricing chain most importantly on import prices and producer prices.

For this purpose, a recursive VAR model is applied which uses the Choleski decomposition method along the distribution chain of pricing ${ }^{17}$. This choice can be justified for several reasons. The so-called distribution chain of pricing is now well established in the existing literature and appears to be the most widely used method, thus providing a means of comparison of the results with those of other studies ${ }^{18}$. Furthermore, when the results are not very sensitive to the ordering of the variables, the Choleski decomposition method can be interpreted as providing robust results.

Accordingly, a VAR model including three endogenous variables - the nominal effective exchange rate (neer), the import price level (imp) and the consumer price index (cpi) - is estimated for each possible pairing in ASEAN5. Therefore, the data is presented in bilateral terms and not in US dollars, which is more commonly used in the literature $^{19}$. In order to retrieve the structural disturbances, $\varepsilon_{t}$, from the reduced-form VAR residuals, $u_{t}$, a Choleski decomposition of the variance-covariance matrix of the reduced form residuals is used as follows:

\footnotetext{
${ }^{17}$ This paper only wants to investigate the degree of exchange rate pass-through along the distribution chain of pricing and not its determinants. Accordingly, other variables normally included in previous studies are dropped here, namely variables to measure demand, monetary and supply shocks.

${ }^{18}$ See for example McCarthy (2000), Hahn (2003) and Ito and Sato (2006).

19 The reason is that one of the purposes of this study is to explain the correlation and adjustment speeds of shocks found among these countries in previous studies. Nevertheless, an analysis which includes all variables in terms of US dollars is also included in the Appendix for completeness.
} 
$\left[\begin{array}{c}u_{t}^{\text {neer }} \\ u_{t}^{\text {imp }} \\ u_{t}^{c p i}\end{array}\right]=\left[\begin{array}{ccc}S_{11} & 0 & 0 \\ S_{21} & S_{22} & 0 \\ S_{31} & S_{32} & S_{33}\end{array}\right] \cdot\left[\begin{array}{c}\varepsilon_{t}^{\text {neer }} \\ \varepsilon_{t}^{i m p} \\ \varepsilon_{t}^{c p i}\end{array}\right]$

The ordering of the variables follows the distribution chain of pricing and reflects the belief that exchange rates do not respond contemporaneously to both import price and domestic price shocks and that import prices do not respond contemporaneously to domestic price shocks.

The data on consumer price index $(2000=100)$ and nominal exchange rates was collected from IMF International Financial Statistics (IFS) database. Data on the nominal effective exchange rate was not available for all countries and therefore had to be generated by applying the IMF trade weights and is constructed so that an increase in the index denotes an appreciation of the currency $(2000=100)^{20}$.

The data on import prices proved to be quite a challenge. The original intent of this study was to use high frequency data as low frequency data might fail to capture most of the pass-through dynamics. A closer analysis on the IFS database, however, showed this to be impossible as no data at any frequency on import prices was available for Indonesia ${ }^{21}$. For Malaysia only annual data for the period 1967-1987 was available, and quarterly data for the Philippines was only available for the period 1996 to 2004. Therefore, annual data from the United Nation's COMTRADE database was compiled for all industries at the Standard International Trade Commodity (SITC) 3-digit level (about 177 industries, depending on the year and country). Next, the import unit values were calculated for all industries on which data was available for all countries simultaneously during the whole sample period. This limited the sample to 46 industries for the period 1967 to 2001 as data for Malaysia in 2002 was not available for any industry $^{22}$. Finally, a weighted average index $(2000=100)$ was generated ${ }^{23}$.

Consequently, all VAR estimations in the next section use annual data for the period between 1967 and 2001. The results are presented in the following section.

\footnotetext{
${ }^{20}$ The method is formally described in Zanuello and Desruelle (1997). The trade weights used on the computations were kindly provided by IMF's Dominique Desruelle.

${ }^{21}$ Ito and Sato (2006) report using monthly data for Indonesia from the CEIC Asia Database. Even this alternative source does not, however, provide data for Malaysia.

${ }^{22}$ The list of the SITC codes of the industries included in the index is presented in Table 1 of the Appendix.

${ }^{23}$ The quality of this index was established by estimating its correlation with the available IMF datasets. The correlation coefficients were found to be 0.77 for Singapore (period: 1974-2001, 28 observations), 0.90 for Thailand (period: 1967-2001, 35 observations) and 0.92 for Malaysia (period: 1967-1987, 21 observations). The correlation was not estimated for the Philippines as the sample available was only 12 observations.
} 


\section{Results}

Following the standard practice, impulse response functions are employed to assess the degree of exchange rate pass-through to domestic prices in ASEAN5. Impulse response functions trace the effects of a shock emanating from an endogenous variable to other variables of the system through the dynamic structure of the VAR.

All endogeneous variables included in the reduced-form VARs are in first differences of logs and were found to be stationary using the common unit root tests ${ }^{24}$. A lag order of either one or two was selected based on the Sequential Modified Likelihood Ratio test for all specifications ${ }^{25}$. The absence of serial autocorrelation in the residuals was confirmed by the Multivariate Lagrange Multiplier test (by failing to reject the null of no serial correlation at the $5 \%$ level of significance).

Figures 1 and 2 of the Appendix present the accumulated response of relative import prices and relative CPI to the nominal effective exchange rate shocks, respectively. The IRFs reported in this study are the accumulated response to Cholesky one standard deviation innovations with a plus and minus 2 standard error confidence intervals using a small sample degrees of freedom correction. The results show evidence of significant but very incomplete exchange rate pass-through to inflation (less than 0.1 of standard deviation of innovations) in all pairs involving Indonesia and the Philippines. For the remaining pairs, the exchange rate pass-through was either insignificant (Thailand-Singapore) or significant but very close to zero (MalaysiaThailand and Malaysia-Singapore). The degree of exchange rate pass-through to import prices was found to be insignificant in all cases with the exception of the pair ThailandSingapore where pass-through was found to be significant but very small (about 0.1 standard deviation of innovations).

The accumulated responses of nominal effective exchange rates to import prices and relative inflation shocks are presented in figures 3 and 4 of the Appendix, respectively, and show that no significant response to import prices shocks was found whilst a significant (albeit very small, with less than 0.125 standard deviation of innovations) response of exchange rates to relative inflation shocks was only found in the case of the pairs Indonesia-Malaysia and Indonesia-Singapore.

\footnotetext{
${ }^{24}$ All VARs were estimated with a constant. As the VAR is to be estimated in first differences, a cointegration analysis was not conducted here.

${ }^{25}$ A VAR with a lag order of one was estimated for the pairs Indonesia-Philippines, Malaysia-Thailand, Philippines-Singapore and Philippines-Thailand. The VARs of all remaining pairs were estimated with two lags.
} 
The accumulated response of import prices to inflation shocks and the accumulated response of relative inflation to import prices shocks are presented in Figure 5 and 6 of the Appendix, respectively, and show the only significant response to be the case of Malaysia-Singapore in both cases.

Next, the statistically significant accumulated responses of each variable in percentage of the standard deviation of each innovation after 2 periods are summarised in Table 1.

Table 1: Accumulated Responses after 2 periods in ASEAN5

\begin{tabular}{|c|c|c|c|c|c|c|}
\hline Country Response of: & IMP & $\mathrm{CPI}$ & NEER & NEER & IMP & $\mathrm{CPI}$ \\
\hline to shocks from & NEER & NEER & IMP & $\mathrm{CPI}$ & $\mathrm{CPI}$ & IMP \\
\hline Indonesia-Malaysia & $x$ & 0.084 & $x$ & -0.062 & $\mathrm{x}$ & $\mathrm{x}$ \\
\hline Indonesia-Philippines & $x$ & 0.104 & $\mathrm{x}$ & $\mathrm{x}$ & -0.060 & $\mathrm{x}$ \\
\hline Indonesia-Singapore & $x$ & 0.092 & $x$ & -0.124 & $x$ & $x$ \\
\hline Indonesia-Thailand & $x$ & 0.075 & $\mathrm{x}$ & $\mathrm{x}$ & $\mathrm{x}$ & $\mathrm{x}$ \\
\hline Malaysia-Philippines & $\mathrm{x}$ & 0.080 & $\mathrm{x}$ & $x$ & $x$ & $X$ \\
\hline Malaysia-Singapore & $x$ & 0.014 & $\mathrm{x}$ & $x$ & -0.044 & -0.015 \\
\hline Malaysia-Thailand & $x$ & 0.017 & $x$ & $\mathrm{x}$ & $x$ & $\mathrm{x}$ \\
\hline Philippines-Singapore & $\mathrm{x}$ & 0.075 & $x$ & $\mathrm{x}$ & $x$ & $x$ \\
\hline Philippines-Thailand & $\mathrm{x}$ & 0.099 & $x$ & $x$ & $x$ & $x$ \\
\hline Thailand-Singapore & 0.164 & $x$ & $x$ & $x$ & $x$ & $x$ \\
\hline
\end{tabular}

Notes: $x=$ no significant response

These results show that with one exception (Thailand-Singapore), there is not expenditure-switching effect in ASEAN5. Also, two cases of a significant response of nominal exchange rates to inflation shocks and one case of a significant response of import prices to an inflation shock exist only in country pairs involving Indonesia. Additionally, dual causality between variables can be identified in several cases $(\mathrm{CPI} \leftrightarrow \mathrm{NEER}$ in the pairs Indonesia-Malaysia and Indonesia-Singapore and IMP $\leftrightarrow \mathrm{CPI}$ in the case of Malaysia-Singapore), therefore reinforcing the need for a VAR estimation procedure. Finally, for the pair Malaysia-Singapore, a simultaneous significant response of import prices to an inflation shock and of inflation to import prices shocks was found suggesting that adjustments in the real exchange rate arise from changes in the domestic price levels as opposed to the nominal exchange rate.

The similarity of the degree of bilateral exchange rate pass-through to relative inflation in the case of Indonesia and the Philippines with their ASEAN partners raises the question of whether this is due to the well-known fact that the US dollar has a large weight in the exchange rate policy of these countries. Table 2 presents the accumulated 
response in percentage of the standard deviation of innovations after 2 periods of the same VARs now estimated with variables in US dollar terms ${ }^{26}$.

Table 2: Accumulated Responses after 2 periods in ASEAN5 (variables in US dollars)

\begin{tabular}{|c|c|c|c|c|c|c|}
\hline \multirow{3}{*}{$\begin{array}{l}\text { Country: } \\
\text { Indonesia } \\
\text { to shocks from }\end{array}$} & IMP & $\mathrm{CPI}$ & NEER & NEER & IMP & $\mathrm{CPI}$ \\
\hline & NEER & NEER & IMP & CPI & $\mathrm{CPI}$ & IMP \\
\hline & $x$ & 0.088 & $x$ & -0.089 & -0.072 & $x$ \\
\hline Malaysia & $x$ & $x$ & $x$ & $x$ & $x$ & 0.022 \\
\hline Philippines & $x$ & 0.050 & $x$ & $x$ & $x$ & $x$ \\
\hline Singapore & $\mathrm{x}$ & $x$ & $x$ & $\mathrm{x}$ & $\mathrm{x}$ & $x$ \\
\hline Thailand & 0.057 & $x$ & $\mathrm{x}$ & $x$ & $x$ & $x$ \\
\hline
\end{tabular}

Notes: $\mathrm{x}=$ no significant response

The results of Table 2 are broadly consistent with those of Table 1 and confirm Indonesia, followed closely by the Philippines, as being the country with the largest degree of exchange rate pass-through to inflation. Also, exchange rate pass-through to import prices is inexistent with the exception of Thailand. Additionally, both nominal exchange rates and import prices respond significantly to inflation shocks in Indonesia suggesting that the nominal exchange rate plays an important role in relative price adjustment. Finally, a significant response of inflation to import prices shocks was only found in Malaysia.

These results are mostly consistent with those of Ito and Sato (2006). In both studies, Indonesia exhibited the largest degree of exchange rate pass-through to inflation of the sample and Malaysia and Singapore revealed no exchange rate pass-through to both import prices and inflation. However, some differences also emerge. Ito and Sato (2006) found evidence that Thailand experienced a small degree of exchange rate passthrough to inflation and that Indonesia yielded a significant and large exchange rate pass-through to import prices. These differences are likely to be due to the fact that they use a different time span (they concentrated on the years immediately before and after the 1997-1998 Asian financial crisis) and a different frequency of data (monthly data).

These collective results have several implications for these countries' prospects of monetary union. A strong case for a rigid exchange rate regime can be made either when there is a total absence of exchange rate pass-through to both import prices and inflation (exchange rate disconnect) as the nominal exchange rate has no adjustment properties and thus a high degree of labour market and wage flexibility must be

\footnotetext{
${ }^{26}$ The lag order set according to the Sequential Modified Likelihood Ratio test was one for Malaysia, Philippines and Thailand, two for Indonesia and three for Singapore.
} 
responsible for the necessary adjustment to shocks, or when there is one-to-one passthrough to domestic inflation (full pass-through) as the nominal exchange rate does not improve the country's competitiveness and destabilizes the inflation rate. In turn, in the case of incomplete pass-through it is difficult to establish any set policy rules. Incomplete pass-through can provide strong support for flexible exchange rates in the cases where the degree of pass-through to import prices is larger than the degree of pass-through to inflation as in this case the nominal exchange rate has some expenditure switching properties. Conversely, when the degree of pass-through to inflation is larger than to import prices, exchange rate flexibility does not help adjusting to asymmetric shocks and may be a source of inflation instability.

Accordingly, a strong case for a common currency can be made for Singapore and Malaysia as they exhibit a case of exchange rate disconnect. For these countries, the necessary adjustment to asymmetric shocks must be coming from wage changes and thus nominal exchange rate is not needed to provide further adjustment.

A case for a rigid exchange rate can also be made for Indonesia but for very different reasons. For this country, the nominal depreciation results in domestic inflation, which in turn affects import prices in a similar way thus offsetting any price competitiveness that could arise from the depreciation. Additionally, the increased inflation results in further depreciation of the currency magnifying the impact of the shocks. In this case, flexible exchange rates are a clear source of shocks to the economy ${ }^{27}$.

The case for the Philippines is less clear-cut, as the only significant response found was an incomplete response of inflation to nominal exchange rate shocks. This suggests that nominal exchange rates destabilise inflation and do not improve the country's competitiveness in the event of a shock which strengthens the case for a fixed currency but also implies a high degree of wage flexibility which would increase the advantages of not joining a currency union.

Finally, for Thailand, a case for flexible exchange rates can be made as import prices respond to exchange rate shocks but inflation rates does not. In this case, a flexible exchange rate is affecting the price faced by domestic consumers of imported goods but not the price of domestic goods and therefore provides a certain degree of expenditure-switching effect.

\footnotetext{
${ }^{27}$ Ito and Sato (2006) show that Indonesia was the only country in their study that responded to the exchange rate shock resulting from the Asian financial crisis by increasing the base money significantly in order to keep commercial banks alive who experienced a serious nonperforming loans problem and in an attempt to maintain financial stability.
} 
The results included in this section, partially explain the pattern of structural shocks found in previous studies ${ }^{28}$. The fact that in those studies, Indonesia was found to have the largest monetary shocks in the grouping and at the same time yielded the lowest correlation coefficients of monetary shocks with its ASEAN partners is explained by Indonesia's central bank monetary policy reaction to shocks to the economy. Also, the very incomplete exchange rate pass-through to domestic prices found in ASEAN5, even in the case of Indonesia and the Philippines, suggests a high degree of labour market and wage rates flexibility which is likely to explain why ASEAN adjusts much faster to structural shocks than either the Euro-zone countries or the USA.

\section{Sensitivity Analysis}

In this section, a series of tests will be conducted to assess the robustness of the results presented in the previous section, focusing on whether the results are sensitive to the ordering of the variables, to the de-trending method and to the frequency of the data.

The major drawback normally attributed to the recursive VAR method is that the results are sensitive to the chosen ordering of the variables as the variables that appear first in the ordering are assumed to have no contemporaneous response to the shocks emanating form the variables that follow. In order to investigate this, several alternative ordering of the variables were tested and the results were identical in all cases. Furthermore, generalised IRFs were also computed and once again the results were identical. An example of the response of inflation to exchange rate shocks estimated with different Choleski ordering of the variables and generalised IRFs (for the pair Indonesia-Malaysia) is presented in Figure 7 of the Appendix.

In order to assess the sensitivity of the results to the de-trending method used, the same VAR systems were re-estimated using HP filtering instead of first differencing of the variables. Figure 8 of the Appendix presents a representative example (again for the pair Indonesia-Malaysia) of the results using the two alternatives methods. Overall, the results proved to be quite insensitive to the de-trending method used.

The disadvantage of using annual data for conducting the estimations on the degree of pass-through is that it might underestimate the degree of exchange rate passthrough as low frequency data is likely to miss important short-run dynamics. In order

\footnotetext{
${ }^{28}$ See Cortinhas (2006) for the estimates on the size, speed of adjustment and correlation coefficients of monetary, demand and supply shocks in the ASEAN5 countries.
} 
to investigate this matter, the same three-variable VAR was estimated for the two countries for which IFS data was available on import unit price indexes on a quarterly basis. Table 2 of the Appendix, compares the results of the accumulated response in percentage of the standard deviation of innovations after 2 periods for Singapore and Thailand, using annual and quarterly data in US dollars ${ }^{29}$. The data for the import prices comes, in this case, from the IFS database (import unit value index), as quarterly data could not be generated for this frequency using the method employed in the previous section. Table 2 of the Appendix shows that, as expected, the use of annual data implies missing some of the shorter term dynamics ${ }^{30}$. In both the case of Singapore and Thailand, the use of quarterly data allows for the identification of some significant (but very small in size) responses that are not captured by the annual data estimations. However, the results from the quarterly data estimations are in line with those from the annual data estimations and therefore, further support validity of the results presented in the previous section.

\section{Final Remarks}

The main contribution of this paper is, for the first time, to investigate the degree of exchange rate pass-through to domestic prices in all five founding members of ASEAN. For this purpose, a three variable recursive VAR model was applied which uses the Choleski decomposition method along the distribution chain of pricing, using data for the period 1968 to 2001.

Based on the evidence of the empirical analysis, a strong case for entering a currency union can only be made for the cases of Singapore and Malaysia as in these countries there appears to be a case of exchange rate disconnect. A case for a common currency can also be made for Indonesia but for entirely different reasons. For this country, an independent monetary policy is a clear source of shocks to the economy and therefore a currency union would tend to eliminate then. However, the costs of entering a currency union would be much larger for Indonesia than for Singapore and Malaysia without the prior strengthening of financial system in that country as domestic commercial banks could not be bailed out by the central bank in the event of a currency

\footnotetext{
${ }^{29}$ Data on the nominal effective exchange rate was once again generated using the IMF weights. The sample for Singapore is 1975 to 2001 and for Thailand is 1968 to 2001 . Quarterly VARs were estimated with quarterly dummies as exogenous variables and with 4 lags for Singapore and 8 for Thailand.

${ }^{30} \mathrm{It}$ is worth noting, however, that the data for imp is not the same for both frequencies. Despite the reasonably high correlation found between the import data generated with COMTRADE data and from the IFS database, it is possible that some of the differences in the results arise from the use of slightly different datasets.
} 
crisis. A weaker case for a common currency can be made for the Philippines as evidence of some exchange rate pass-through to inflation was found but not to import prices. Finally, Thailand exhibits a clear case of exchange rate pass-through to import prices (but not to inflation) and thus evidence that a flexible exchange rate might be preferable as it provides the means to improve the country's price competitiveness. The sensitivity analysis showed the results to be very similar independently of the ordering of the variables and the de-trending method used. Also, it showed that although the use of quarterly data allows for the identification of a larger number of significant responses, the results are consistent with the results from annual data estimations.

In this way, this study provides further evidence of the existence of a core group of countries, comprised of mainly Malaysia and Singapore but also by Indonesia, which is better prepared for monetary union than a periphery comprising the Philippines and Thailand. 


\section{References}

An, L., 2006, Exchange Rate Pass-Through: Evidence Based on Vector Autoregression with Sign Restrictions, MPRA Paper 527, University Library of Munich.

Artis, M. and Ehrmann, M., 2006, The Exchange Rate - A Shock-Absorber or Source of Shocks? A Study of Four Open Economies, Journal of International Money and Finance, 25, p. 874-893.

Bache, I., 2006, Assessing the Structural VAR Approach to Exchange Rate PassThrough, Computing in Economics and Finance 2006, 309, Society for Computational Economics.

Barhoumi, K., 2006, Differences in Long Run Exchange Rate Pass-Through into Import Prices in Developing Countries: An Empirical Investigation, Economic Modelling, 23, 926-951.

Bayoumi, T. and Eichengreen, B., 1994, One Money or Many? On analysing the prospects for monetary unification in various parts of the World, Princeton Essays in International Finance no. 76, International Finance Section, Princeton.

Bayoumi, T. and Eichengreen, B., 1996, Operationalizing the Theory of Optimum Currency Areas, CEPR Discussion Paper no. 1484.

Bayoumi, T., Eichengreen, B. and Mauro, P., 2000, On Regional Monetary Arrangements for ASEAN, Journal of Japanese and International Economics, 14, 121-148.

Bayoumi, T. and Mauro, P., 2001, The Suitability of ASEAN for a Regional Currency Arrangement, World Economy, 24, 933-945.

Bayoumi, T. and Thomas, 1995, Relative Prices and Economic Adjustment in the U. S. and the EU: A Real Story About European Monetary Union, IMF Working Paper 94-65.

Buitter, W., 2000, Optimal Currency Areas, Scottish Journal of Political Economy, 47 (3), 213-249.

Calvo, G. and Reinhart, C., 2002, Fear of Floating, Quarterly Journal of Economics, 117, 379-408. 
Campa, J. and Goldberg, L., 2005, Exchange Rate Pass-Through into Import Prices, Review of Economics and Statistics, 87(4), 679-690.

Choudri, E., Faruquee, H. and Hakura, D., 2005, Explaining the Exchange Rate PassThrough in Different Prices, Journal of International Economics, 65, 349-374.

Choudri, E. and Hakura, D., 2006, Exchange Rate Pass-Through to Domestic Prices: Does the Inflationary Environment Matter?, Journal of International Money and Finance, 25, 614-639.

Cortinhas, C., 2006, Asymmetry of Shocks and Covergence in Selected Asean Countries: A Dynamic Analysis, NIPE Working Papers, 3/2006.

Devereux, M. and Engel, C., 2003, Monetary Policy in the Open Economy Revisited: Price Setting and Exchange Rate Flexibility, Review of Economic Studies, 70, 765-783.

Duarte, M., 2004, Monetary Policy and the Adjustment to Country-Specific Shocks, Federal Reserve Bank of Richmond Economic Quarterly, 90, 21-40.

Duarte, M. and Obstfeld, M., 2004, Monetary Policy in the Open Economy Revisited: The Case for Exchange-Rate Flexibility Restored, Society for Economic Dynamics Meeting Papers, no. 386.

Engel, C., Hendrickson, M.K. and Rogers, J.H., 1997, Intranational, Intracontinental, and Intraplanetary PPP, Journal of the Japanese and International Economies, $11,480-501$.

Frankel, J. and Rose, A., 1997, Is EMU More Justifiable ex post than ex ante?, European Economic Review, 41, 753-760.

Frankel, J. And Rose, A., 1998, The Endogeneity of the Optimum Currency Area Criteria”, Economic Journal, 108, 1009-1025.

Gagnong, J. and Ihrig, J., 2004, Monetary Policy and Exchange Rate Pass-Through, International Journal of Finance and Economics, 9, 315-338.

Goldberg, P. and Knetter, M., 1997, Goods Prices and Exchange Rates: What Have We Learned?, Journal of Economic Literature, 35, 1243-1272.

Hahn, E., 2003, Pass-Through of External Shocks to Euro Area Inflation, ECB Working Paper, 243.

Ito, T. and Sato, K., 2006, Exchange Rate Changes and Inflation in Post-Crisis Asian Economies: VAR Analysis of the Exchange Rate Pass-Through, NBER Working Paper, 12395. 
Ito, T., Sasaki, Y. and Sato, K., 2005, Pass-Through of Exchange Rate Changes and Macroeconomic Shocks to Domestic Inflation in East Asian Countries, RIETI Discussion Paper Series, 05-E-020.

McCarhty, J., 2000, Pass-Through to Exchange Rates and Import Prices to Domestic Inflation in Some Industrialized Countries, Federal Reserve Bank of New York, Staff Reports, 111.

Menon, J., 1995, Exchange Rate Pass-Through, Journal of Economic Surveys, 9, 197231.

Mihailov, A., 2005, Exchange Rate Pass-Through on Prices in Macrodata: A Comparative Sensitivity Analysis, University of Essex Economics Discussion Papers, 568.

Obstfeld, M., 2006, Pricing-to-Market, The Interest-Rate Rule, and the Exchange Rate, NBER Working Paper 12699, November.

Parsons, C. and Sato, K., 2005, Exchange Rate Pass-Through in East Asia, CITS Working Paper, 2005-09.

Rogers, J.H. and Jenkins, M., 1995, Haircuts or Hysteresis? Sources of Movements in Real Exchange Rates, Journal of International Economics, 38, 339-360.

Rose, A. and Engel, C., 2002, Currency Unions and International Integration, Journal of Money, Credit and Banking, 34 (4), 1067-1089.

Taylor, J., 2000, Low Inflation, Pass-Through, and the Pricing Power of Firms, European Economic Review, 44(7), 1389-1408.

Toh, M. and Ho, H., 2001, Exchange Rate Pass-Through for Selected Asian Economies, The Singapore Economic Review, 46(2), 247-273.

Weber, A., 1999, Dynamic and Long Run Responses of Import Prices to the Exchange Rate in the Asia-Pacific, Asian Economic Journal, 13(3), 303-320.

Yuen, H., 2000, Is Asia an Optimum Currency Area? "Shocking” Aspects of Output Fluctuations in East Asia, National University of Singapore Working Paper.

Zanello, A. and Desruelle, D., 1997, A Primer on the IMF's Information Notice System, IMF Working Paper, WP/97/71.

Zhang, Z. and Sato, K. and McAleer, M., 2004, Is a Monetary Union Feasible for East Asia?, Applied Economics, 36, 1031-1043. 


\section{Appendix}

Table 1: Description of the industries included in the import unit value index (imp)

\begin{tabular}{|l|c|l|}
\hline \multicolumn{1}{|c|}{ Commodity Class } & $\begin{array}{c}\text { No. of } \\
\text { industries }\end{array}$ & \multicolumn{1}{|c|}{ SITC Codes } \\
\hline 0 - Food and live animals & 19 & $\begin{array}{l}11,12,13,23,44,46,47,48,51,52,54,55, \\
61,62,72,73,74,75,81\end{array}$ \\
\hline $\begin{array}{l}\text { 2 - Crude materials, inedible, } \\
\text { except fuels }\end{array}$ & 4 & $231,251,273,276$ \\
\hline $\begin{array}{l}\text { 3 - Mineral fuels, lubricants } \\
\text { and related materials }\end{array}$ & 2 & 321,332 \\
\hline $\begin{array}{l}4 \text { - Animal and vegetable oils } \\
\text { and fats }\end{array}$ & 3 & $411,421,422$ \\
\hline 5 - Chemicals & 5 & $514,531,532,551,561$ \\
\hline $\begin{array}{l}\text { - Manufactured goods } \\
\text { classified chiefly by material }\end{array}$ & 13 & $\begin{array}{l}611,641,661,673,674,676,677,682,683, \\
684,685,686,693\end{array}$ \\
\hline
\end{tabular}


Figure 1: Accumulated Impulse Response of Import Prices to the Exchange Rates Shock
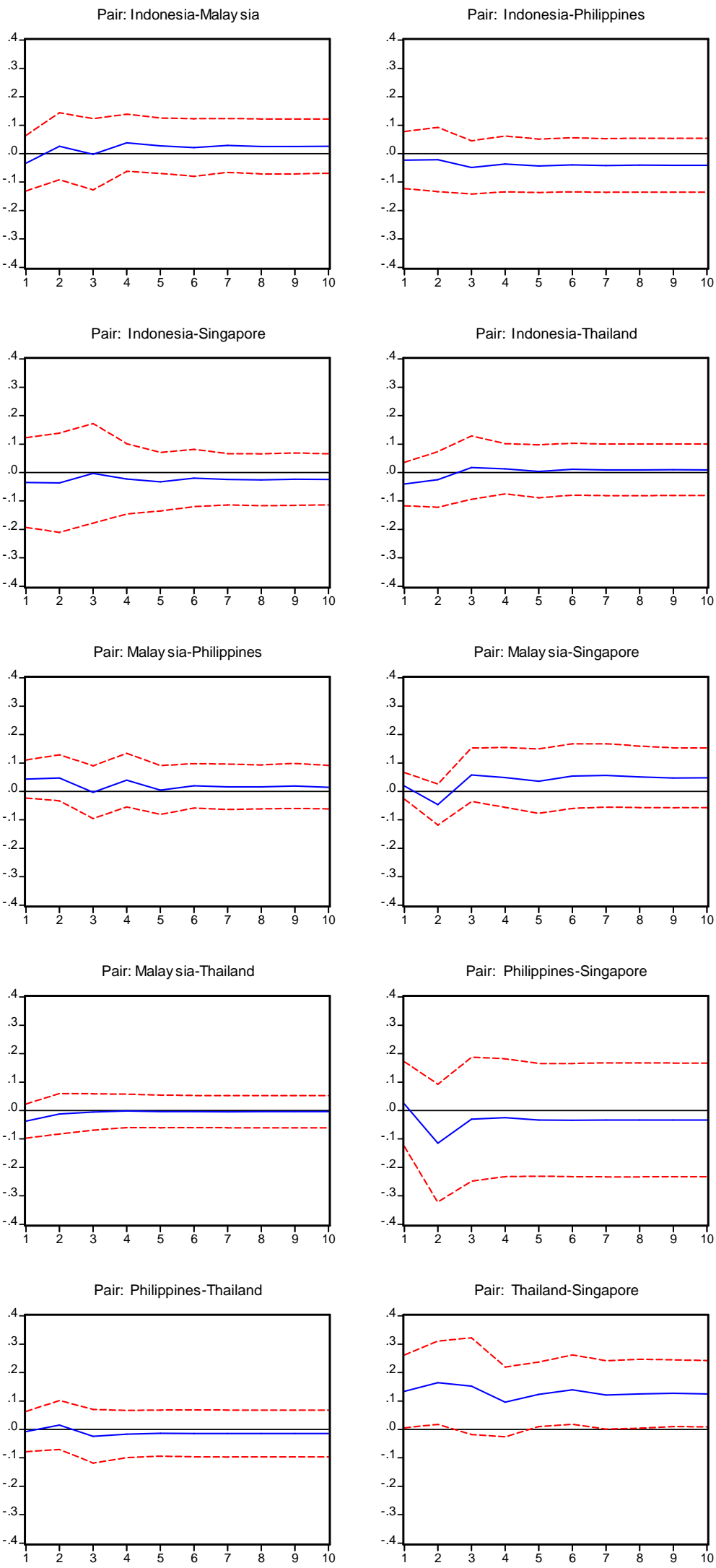
Figure 2: Accumulated Impulse Response of relative CPI to the Exchange Rate Shock
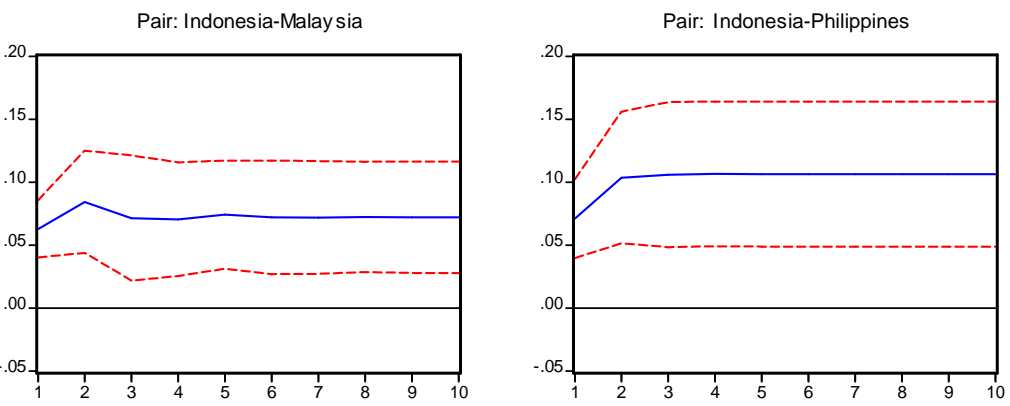

Pair: Indonesia-Singapore
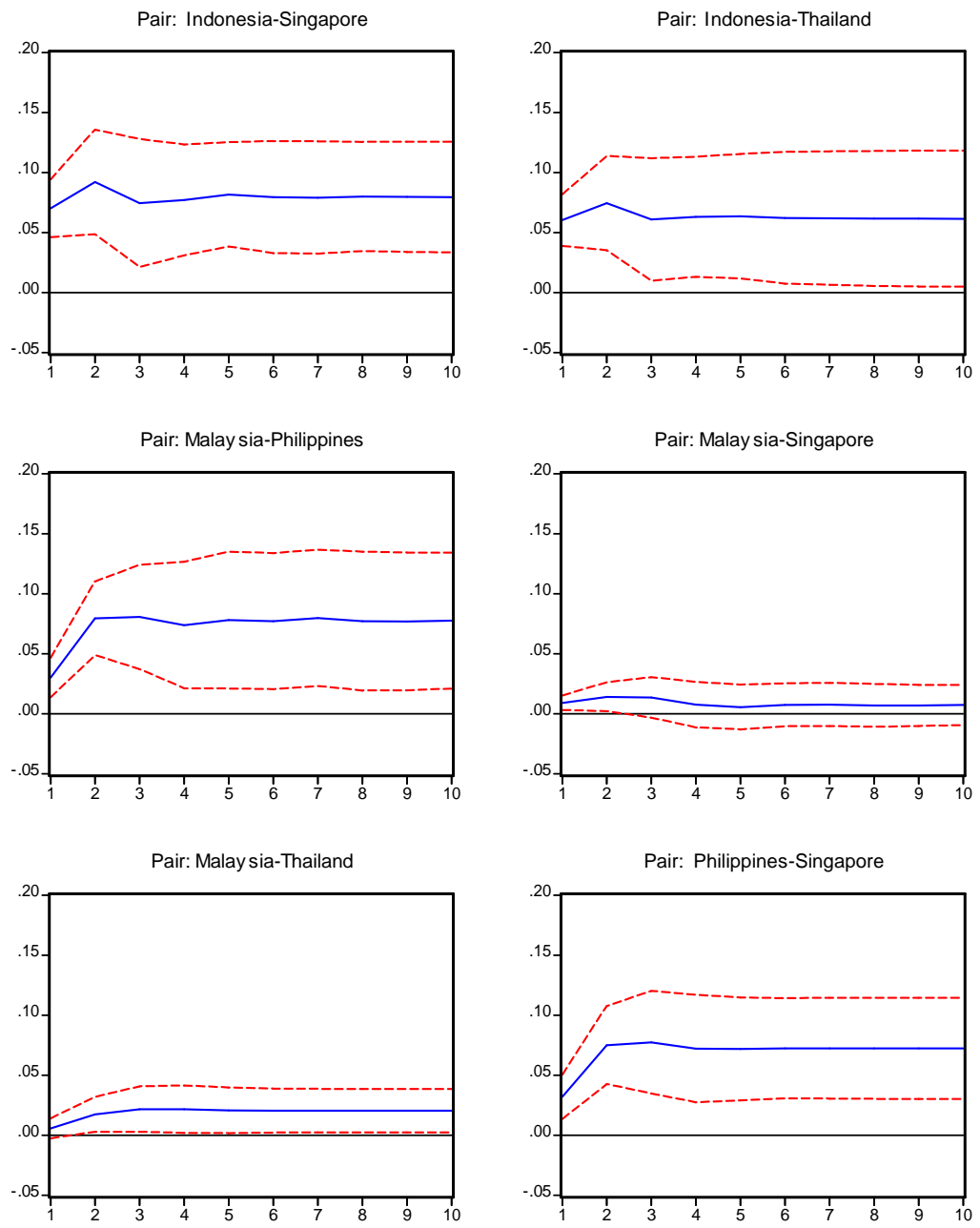

Pair: Philippines-Thailand

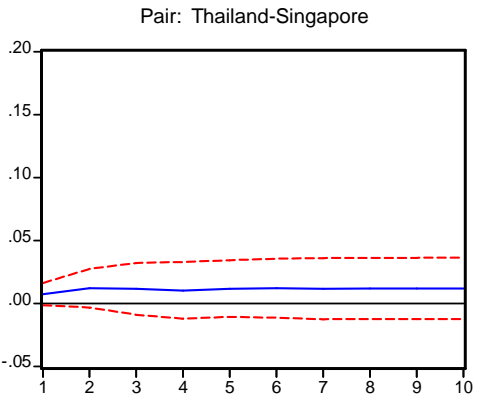


Figure 3: Accumulated Impulse Response of Exchange Rates to the Import Prices Shock
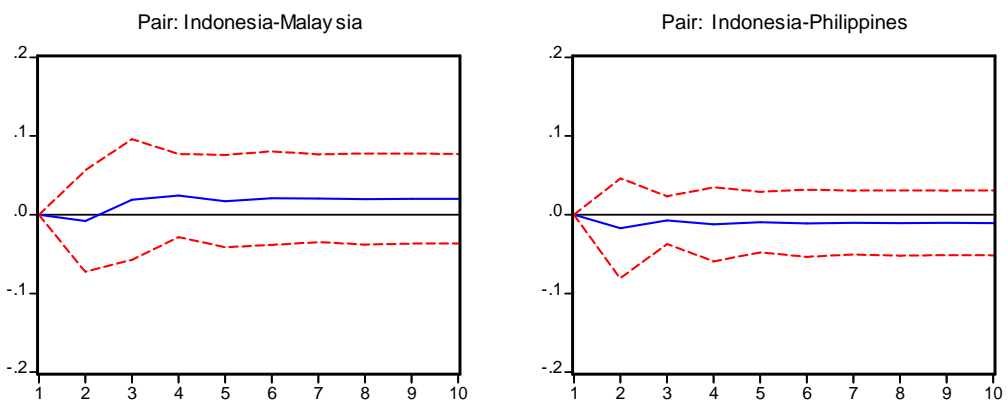

Pair: Indonesia-Singapore
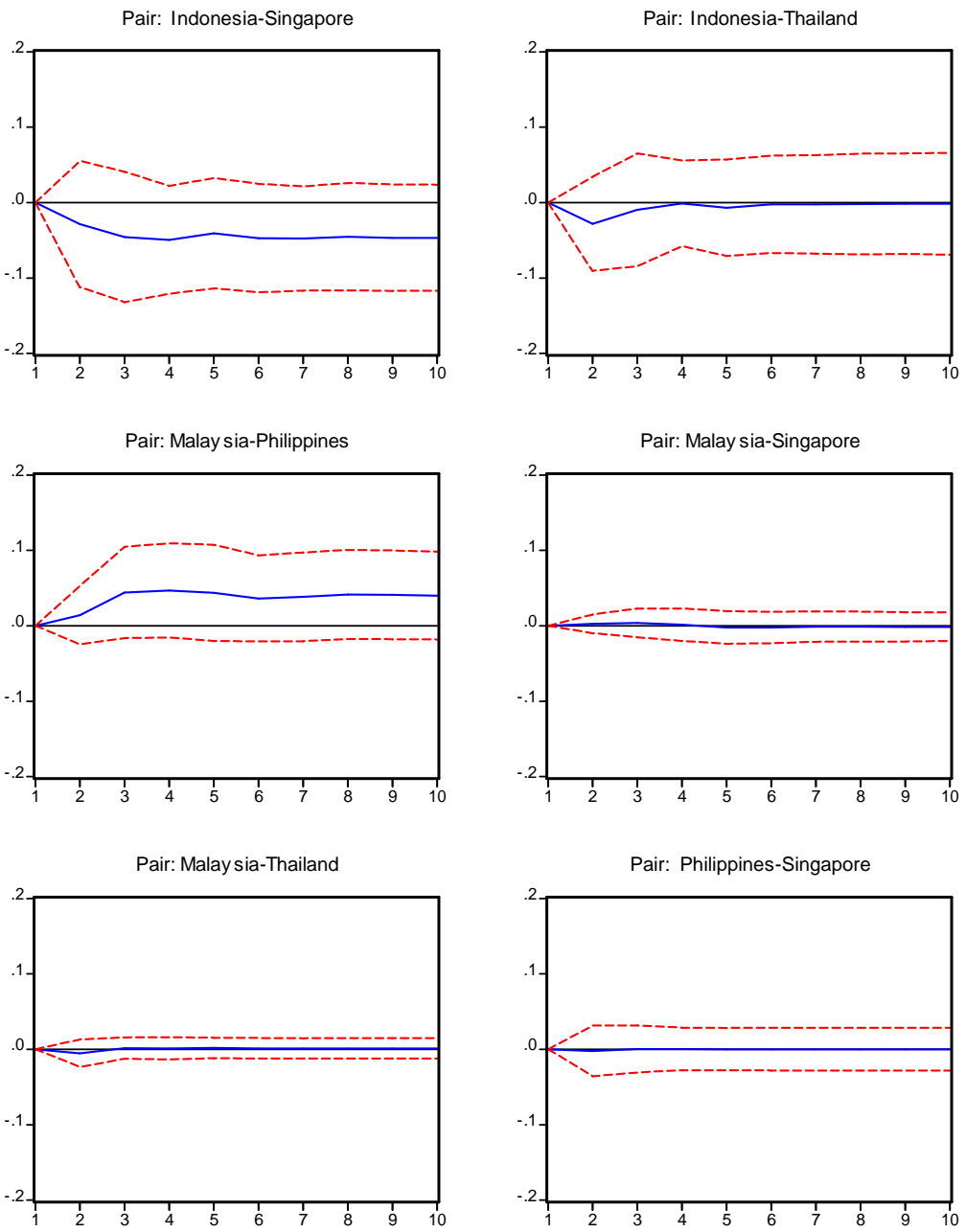

Pair: Philippines-Thailand

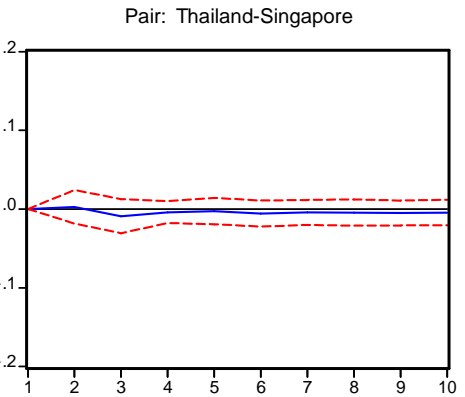


Figure 4: Accumulated Impulse Response of Exchange Rates to the relative CPI Shock
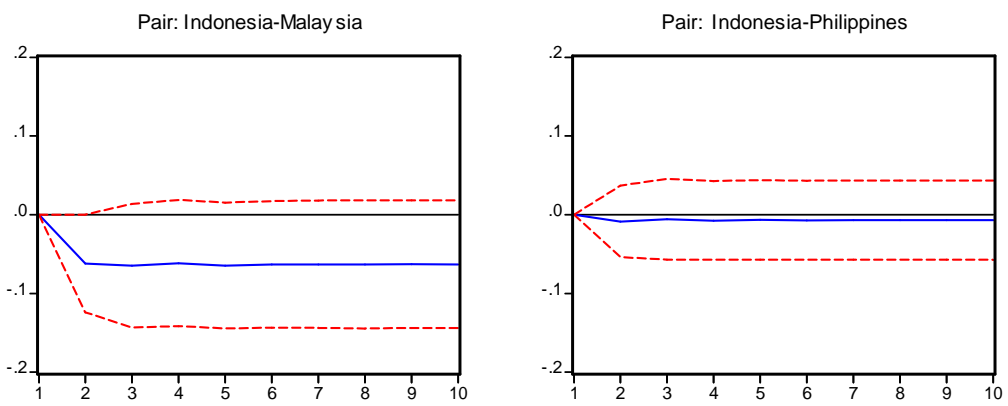

Pair: Indonesia-Singapore
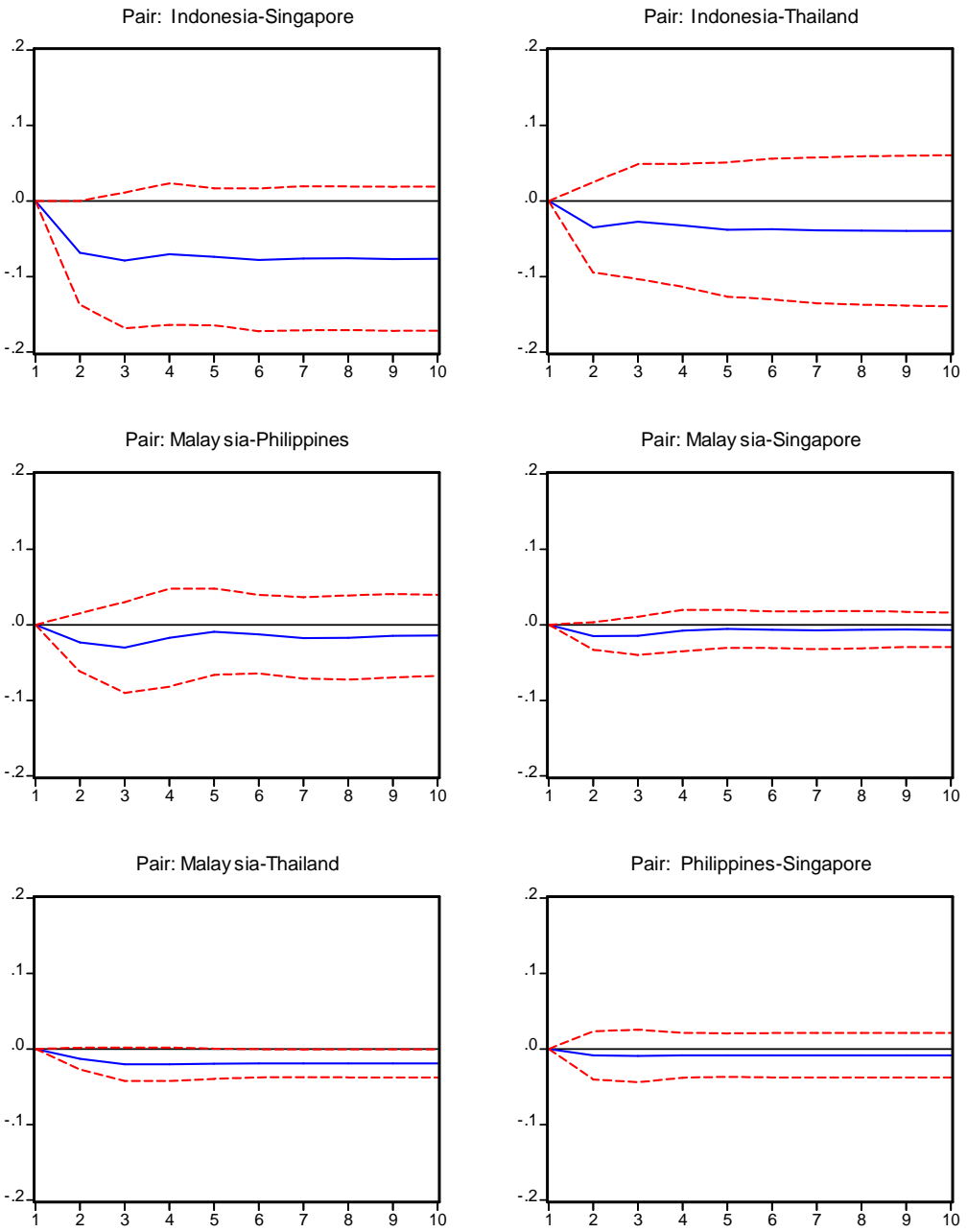

Pair: Philippines-Thailand

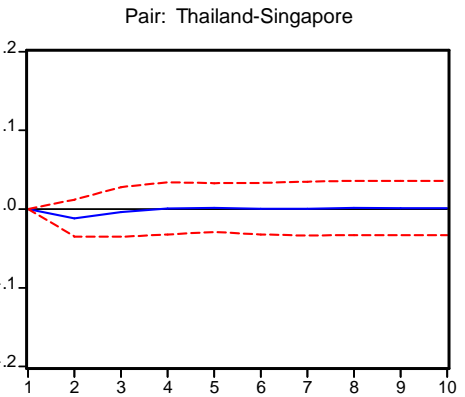


Figure 5: Accumulated Impulse Response of Import Prices to the relative CPI Shock
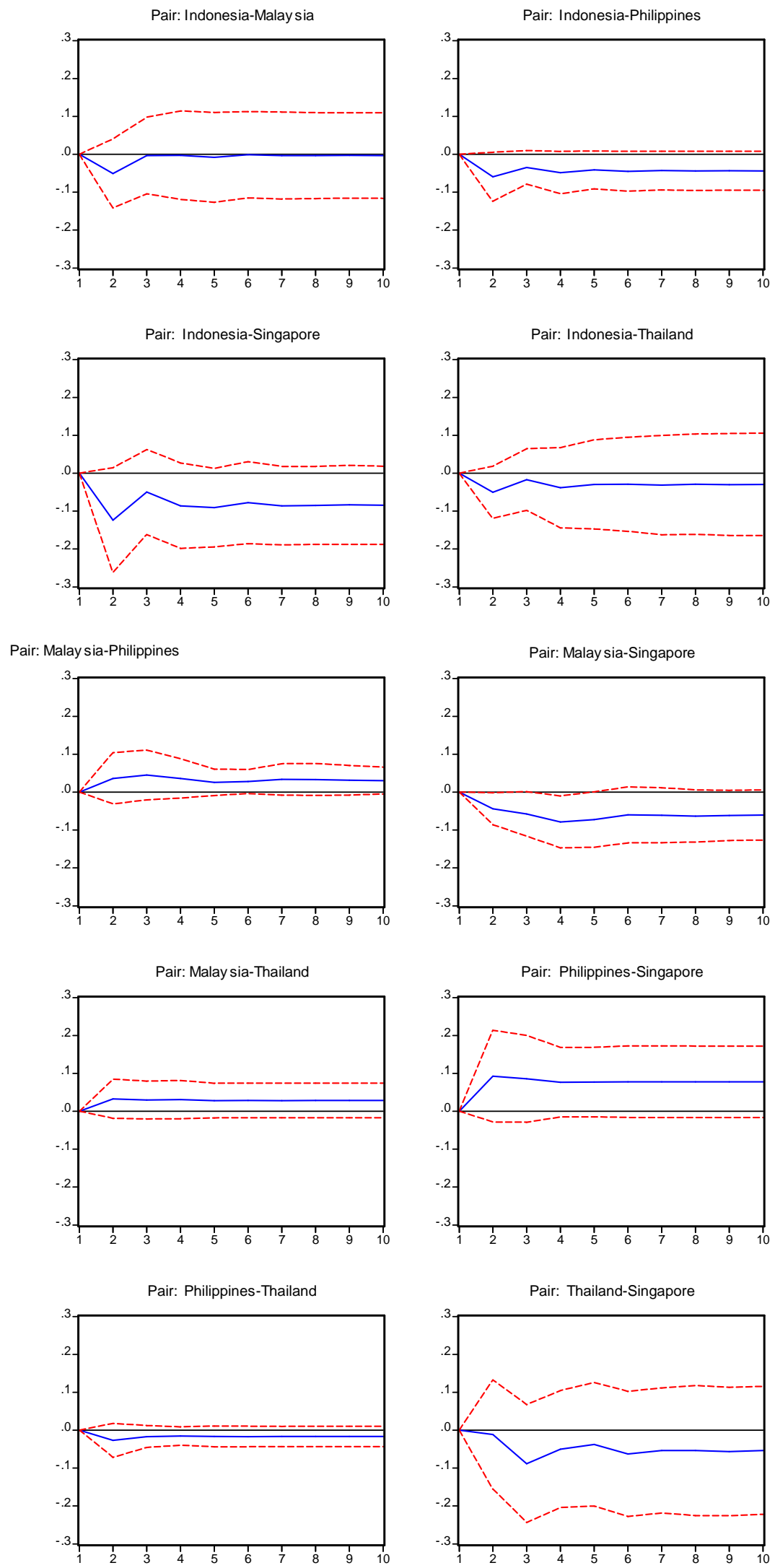
Figure 6: Accumulated Impulse Response of relative CPI to the Import Prices Shock
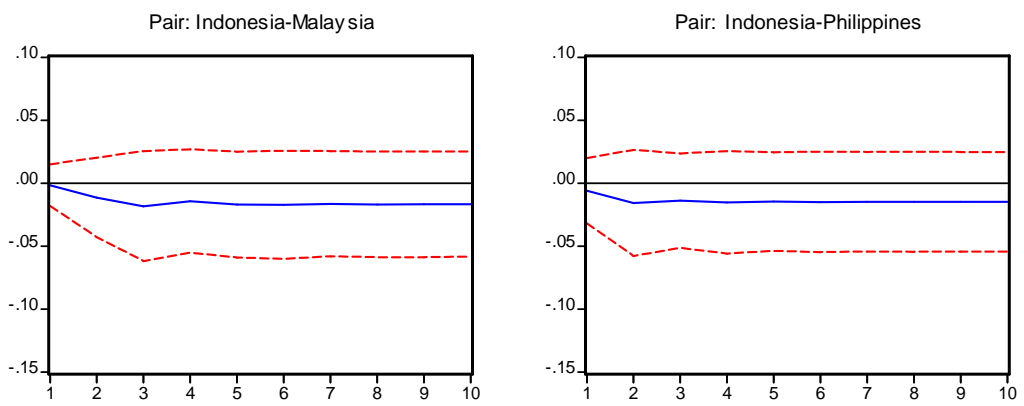

Pair: Indonesia-Singapore
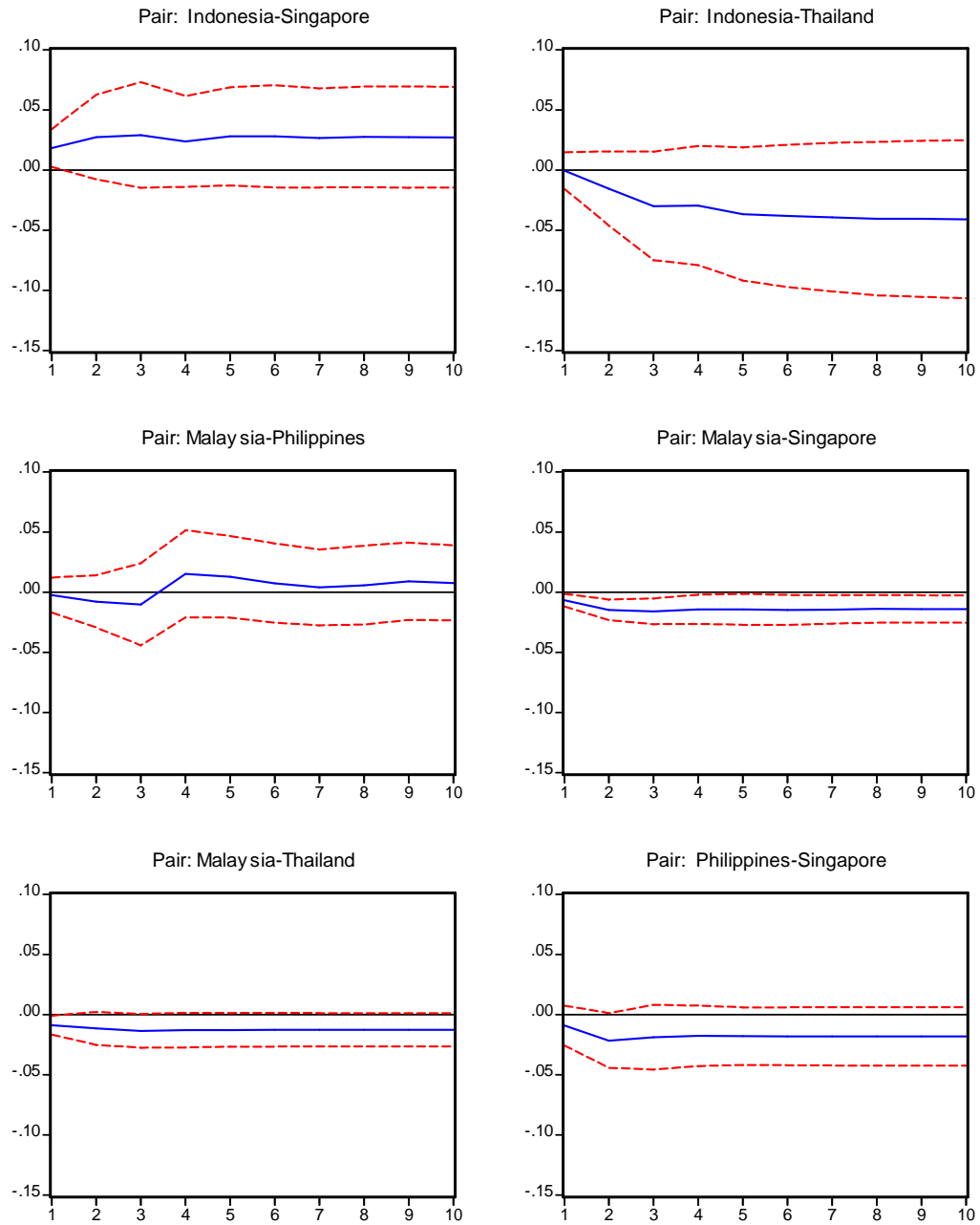

Pair: Philippines-Thailand

Pair: Thailand-Singapore
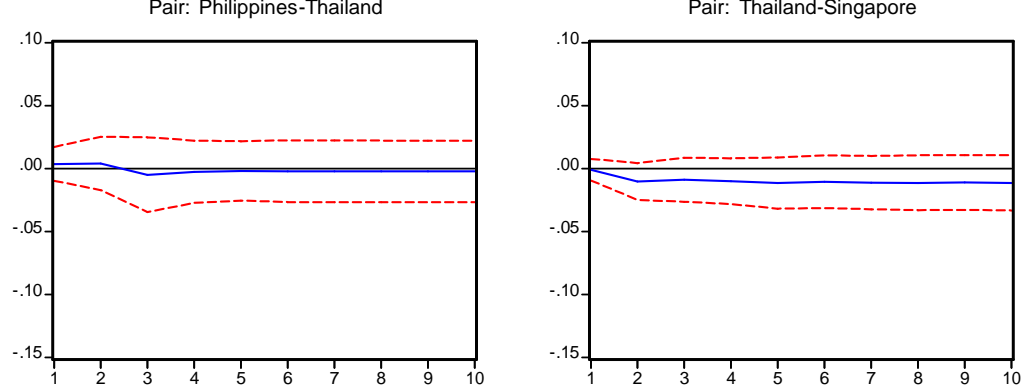
Figure 7: Accumulated IRFs using different Choleski orderings and impulse definitions

Response of inflation to NEER

Response of Inflation to NEER (Choleski ordering: NEER, Import Prices and Inflation) (Choleski ordering: Import Prices, NEER, Inflation) Pair: Indonesia-Malaysia

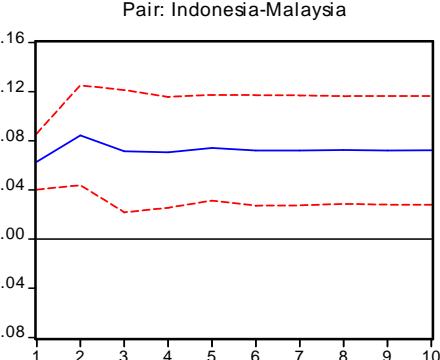

Response of Inflation to NEER Generalised Impulse-Response Function Pair: Indonesia-Malaysia
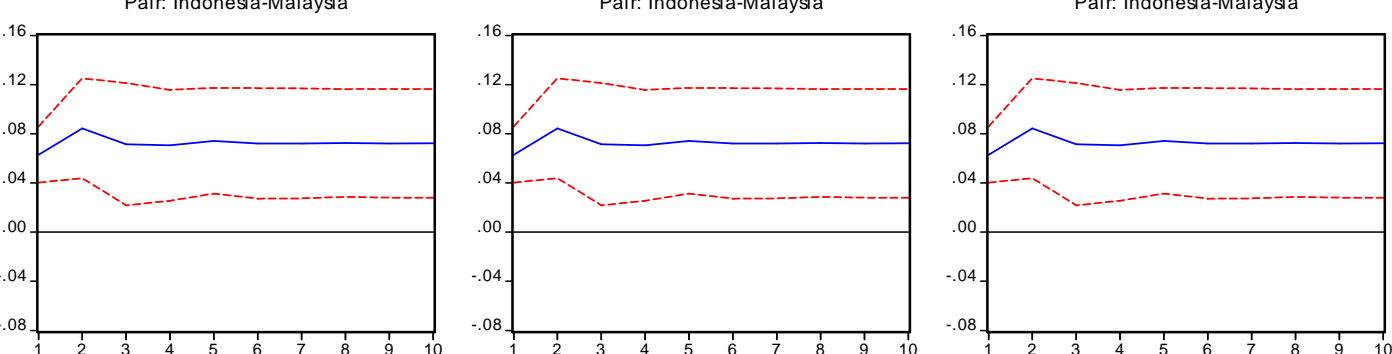

Figure 8: Accumulated IRFs using different de-trending methods
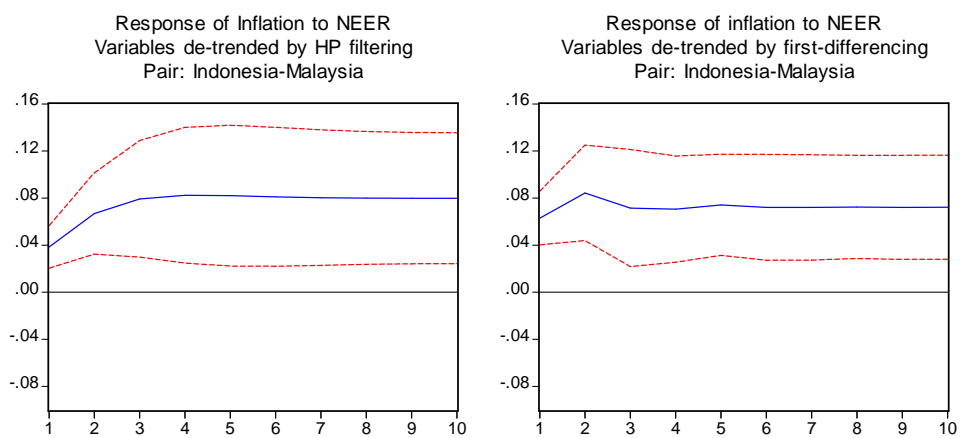

Table 2: Accumulated Responses after 2 periods in ASEAN5 - Annual and quarterly Data

\begin{tabular}{|c|c|c|c|c|c|c|}
\hline Response of: & IMP & $\mathrm{CPI}$ & NEER & NEER & IMP & $\mathrm{CPI}$ \\
\hline Country: to shocks from & NEER & NEER & IMP & $\mathrm{CPI}$ & $\mathrm{CPI}$ & IMP \\
\hline Singapore (annual data) & $x$ & $x$ & $x$ & $x$ & $x$ & $X$ \\
\hline Singapore (quarterly data) & $x$ & $\mathrm{x}$ & -0.008 & $x$ & $\mathrm{x}$ & 0.002 \\
\hline Thailand (annual data) & 0.057 & $\mathrm{x}$ & $x$ & $\mathrm{x}$ & $\mathrm{x}$ & $x$ \\
\hline Thailand (quarterly data) & 0.016 & $\mathrm{x}$ & $x$ & $x$ & 0.012 & 0.005 \\
\hline
\end{tabular}

Notes: $x=$ no significant response. Data Range is 1975 to 2001 for Singapore and 1968 to 2001 for Thailand. 
This document was created with Win2PDF available at http://www.win2pdf.com.

The unregistered version of Win2PDF is for evaluation or non-commercial use only. This page will not be added after purchasing Win2PDF. 